Vol. 6, No. 1, Februari 2018

Efektifitas Media Film dengan Leaflet dalam Peningkatan Pengetahuan Ibu Rumah Tangga tentang DBD di Desa Pekalongan Kabupaten Pati

Dobby Raka Sandi Susetya, Ervi Rachma Dewi

Menggali Kefektifan Peran Ibu dengan Anak Usia Pra Sekolah selama Berada di Rutan Kudus Aliani Nailil Izzah, Sri Hindriyastuti

Perbedaan Kadar BOD Limbah Cair Sebelum dan Setelah melewati Biofilter Tanaman Cattail (Typha angustifolia) Pujo Prasetyo, David Laksamana Caesar

Gambaran Kepatuhan Ibu dalam Pelaksanaan Imunisasi DPT/Hb Lengkap di Puskesmas Punggelan 2 Kabupaten Banjarnegara Lia Aria Ratmawati, Rosiyani Hermawati

Hubungan Riwayat Kontak Penderita dengan Kejadian Tuberkulosis Paru Anak Usia 1-14 Tahun di Balai Kesehatan Masyarakat Pati Risna Endah Budiati, Noor Khoirina

Hubungan Dukungan Keluarga dengan Pemberian ASI Eksklusif pada Bayi di Desa Jambean Kidul Kecamatan Margorejo Nanik Royaningsih, Sri Wahyuningsih

Jumlah Kehamilan dan Kematian Ibu Berdasarkan Letak Wilayah Ketinggian di Kabupaten Pekalongan Rokhani, Indri Astuti Purwanti 


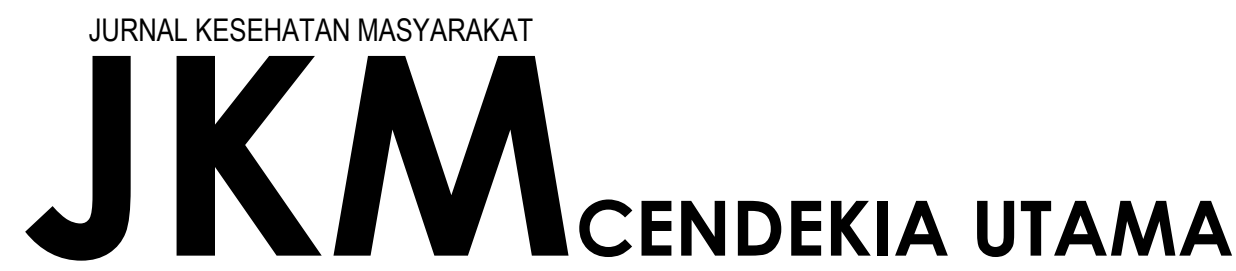


Vol. 6 No. 1

P-ISSN 2338-6347

Februari, 2018

E-ISSN 2580-992X

\section{$\mathbf{J} \mathbf{M}_{\text {cendekia utama }}$}

\section{Editor in Chief}

Eko Prasetyo, S.KM., M.Kes. STIKES Cendekia Utama Kudus, Indonesia

\section{Editorial Board}

Sri Wahyuningsih, S.KM., M.Gizi., STIKES Cendekia Utama Kudus, Indonesia Risna Endah Budiati, S.KM., M.Kes., (Epid), STIKES Cendekia Utama Kudus, Indonesia

Ervi Rachma Dewi, S.KM., M.Kes., STIKES Cendekia Utama Kudus, Indonesia David Laksamana Caesar, S.KM., M.Kes., STIKES Cendekia Utama Kudus, Indonesia

\section{Reviewer}

Sigit Ari Saputro, S.KM., M.Kes., Universitas Airlangga, Surabaya, Indonesia dr. Mahalul Azam, M.Kes., Universitas Negeri Semarang, Indonesia

Eti Rimawati, S.KM., M.Kes., Universitas Dian Nuswantoro, Semarang, Indonesia Didik Sumanto, S.KM., M.Kes. (Epid), Universitas Muhammadiyah Semarang, Indonesia

\section{English Language Editor}

Arina Hafadhotul Husna, M.Pd., STIKES Cendekia Utama Kudus, Indonesia

\section{IT Support}

Susilo Restu Wahyuno, S.Kom, STIKES Cendekia Utama Kudus, Indonesia

JKM (Jurnal Kesehatan Masyarakat) Cendekia Utama merupakan jurnal ilmiah dalam bidang kesehatan masyarakat yang diterbitkan oleh Program

Studi S1 IImu Kesehatan Masyarakat STIKES Cendekia Utama Kudus secara berkala dua kali dalam satu tahun 


\section{KATA PENGANTAR}

Salam MIRACLE,

Puji syukur selalu senantiasa kita panjatkan kehadirat Allah SWT yang telah melimpahkan Rahmah Hidayah dan Ilmu-Nya, sehingga JKM (Jurnal Kesehatan Masyarakat) Cendekia Utama Kudus Vol. 6, No. 1 dapat kembali terbit pada bulan Februari 2018 ini. Pada kesempatan yang baik ini kami menyampaikan ucapan terima kasih dan apresiasi yang setinggi-tingginya kepada bapak ibu mitra bestari, para peneliti, tim redaksi, dan semua pihak yang telah mendukung atas terbitnya JKM Cendekia Utama Vol. 6, No. 1 ini.

JKM Cendekia Utama merupakan jurnal ilmiah di bidang kesehatan masyarakat yang diterbitkan secara berkala 2 (dua) kali dalam setahun oleh Program Studi S1 Ilmu Kesehatan Masyarakat STIKES Cendekia Utama Kudus. JKM Cendekia Utama mempublikasikan informasi ilmiah hasil penelitian dengan kajian: Epidemiologi, Kesehatan Lingkungan, Keselamatan dan Kesehatan Kerja (K3), Promosi Kesehatan, Biostatistik dan Kependudukan, Administrasi Kebijakan Kesehatan (AKK), Manajemen Kesehatan, Gizi Masyarakat, Kesehatan Ibu dan Anak (KIA), Kesehatan Reproduksi, dan kajian-kajian pengembangan ilmu di bidang kesehatan masyarakat.

JKM Cendekia Utama kembali mengundang berbagai ilmuan dari berbagai lembaga pendidikan tinggi maupun peneliti untuk memberikan sumbangan ilmiahnya dalam bentuk artikel ilmiah dari hasil penelitian, laporan/studi kasus, kajian/tinjauan pustaka di bidang kesehatan masyarakat dalam rangka mengatasi permasalahan kesehatan masyarakat yang semakin kompleks.

Redaksi sangat mengharapkan masukan-masukan dari para pembaca dan professional bidang kesehatan masyarakat untuk peningkatan kualitas jurnal dan berharap semoga artikel-artikelyang termuat dalam JKM Cendekia Utama bermanfaat dalam pengembangan ilmu di bidang kesehatan masyarakat.

\section{Pimpinan Redaksi}

Eko Prasetyo, S.KM., M.Kes. 


\section{DAFTAR ISI}

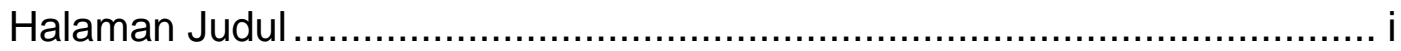

Susunan Dewan Redaksi..................................................................

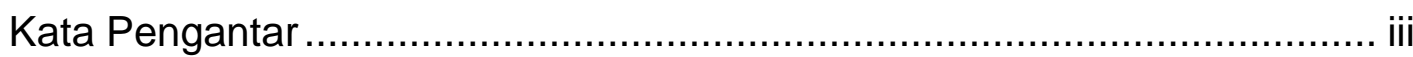

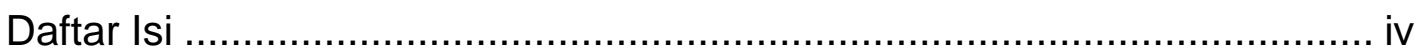

Efektifitas Media Film dengan Leaflet dalam Peningkatan Pengetahuan Ibu Rumah Tangga tentang DBD di Desa Pekalongan Kabupaten Pati Dobby Raka Sandi Susetya, Ervi Rachma Dewi........................................ 1

Menggali Kefektifan Peran Ibu dengan Anak Usia Pra Sekolah selama Berada di Rutan Kudus

Aliani Nailil Izzah, Sri Hindriyastuti........................................................ 16

Perbedaan Kadar BOD Limbah Cair Sebelum dan Setelah melewati Biofilter Tanaman Cattail (Typha angustifolia)

Pujo Prasetyo, David Laksamana Caesar

Gambaran Kepatuhan Ibu dalam Pelaksanaan Imunisasi DPT/Hb Lengkap di Puskesmas Punggelan 2 Kabupaten Banjarnegara

Hubungan Riwayat Kontak Penderita dengan Kejadian Tuberkulosis Paru Anak Usia 1-14 Tahun di Balai Kesehatan Masyarakat Pati Risna Endah Budiati, Noor Khoirina.

Hubungan Dukungan Keluarga dengan Pemberian ASI Eksklusif pada Bayi di Desa Jambean Kidul Kecamatan Margorejo

Jumlah Kehamilan dan Kematian Ibu Berdasarkan Letak Wilayah Ketinggian di Kabupaten Pekalongan

Rokhani, Indri Astuti Purwanti 62

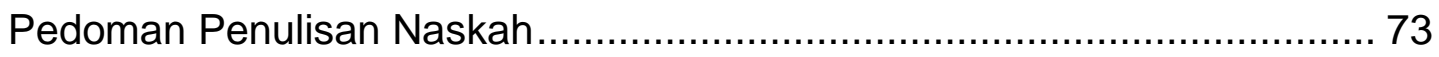

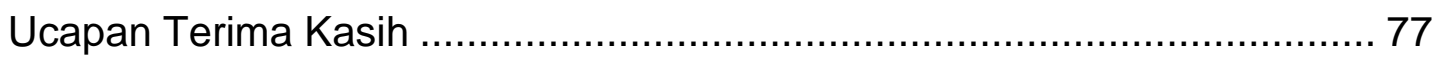




\title{
JUMLAH KEHAMILAN DAN KEMATIAN IBU BERDASARKAN LETAK WILAYAH KETINGGIAN DI KABUPATEN PEKALONGAN
}

\author{
Rokhani ${ }^{1}$, Indri Astuti Purwanti ${ }^{2}$ \\ 1,2Universitas Muhammadiyah Semarang \\ Email: roysukendar79@gmail.com
}

\begin{abstract}
ABSTRAK
Angka kematian ibu menjadi salah satu indikator keberhasilan suatu negara. Di Indosesia angka kematian ibu jumlahnya bervariasi setiap tahun, dan salah satu wilayah dengan jumlah kematian ibu yang relatif tinggi adalah Jawa Tengah dengan beberapa daerah kabupaten/kota yang ada dibawahnya. Tingginya angka kematian ibu disebabkan oleh berbagai faktor yang berhubungan dengan proses kejadian kematian ibu (determinan dekat) dan bersama-sama dengan determinan antara dan determinan jauh. Salah satu determinan yang sering diperhatian adalah keadaan geografis yang berhubungan dengan keadaan ketinggian suatu wilayah. Tujuan penelitian ini adalah untuk melihat jumlah ibu hamil, kematian yang terjadi pada ibu hamil dan sebab kematian yang ada pada ibu hamil berdasarkan ketinggian suatu wilayah. Penelitian ini menggunakan explanatory research dengan pendekatan cross-sectional dan analisa deskriptif pada wilayah kecamatan di Kabupaten Pekalongan.. Hasil dari penelitian ini adalah $85,79 \%$ ibu hamil ada diwilayah dataran rendah, 88,88\% kematian ibu hamil ada diwilayah dataran rendah dan $77,77 \%$ kematian ibu hamil disebabkan oleh pre-eklamsia/eklamsia.
\end{abstract}

Kata kunci: Jumlah Ibu hamil, Jumlah Kematian Ibu, Ketinggian Area.

\begin{abstract}
Maternal Mortality Rate (MMR) is a success indicator of the country. The maternal mortality rate in Indonesia relatively high rate every years. In Central Java Province also have a high maternal mortality rate with the districts below. The maternal mortality rate is due to various factors relate maternal mortality process (closed determinant) and together with the other determinant.the observed determinan mostly has geographic state and assosiate the attitude of a area. The purpose of this study to aim the number of pregnat women. Maternal mortality and the couse of that case base of the height of area. This research uses explanatory research with cross-sectional approach and descriptive analysis. The risult of this research is $85,79 \%$ pregnant women in lowland area. $88,88 \%$ maternal mortality in a lowland area and $77,77 \%$ deathly case caused by pre-eclampsia./eclampsia.
\end{abstract}

Keyword: Maternal Pregnant, Maternal Mortality, Latitude Area 


\section{PENDAHULUAN}

Angka Kematian Ibu (AKI) menjadi salah satu indikator penting keberhasilan suatu negara dalam memberikan kesejahteraan bagi rakyatnya. Di Idonesia angka kematian ibu jumlahnya bervariasi setiap tahunnya, dari tahun 1991 terdapat 390 jiwa / 100.000 kelahiran hidup. Jumlah tersebut terus menurun hingga tahun 2007 menjadi 228 jiwa / 100.000 kelahiran hidup. Pada tahun 2012 terjadi peningkatan yang sangat signifikan menjadi 359 jiwa / 100.000 kelahiran hidup, dan kembali turun di tahun 2015 menjadi 305 jiwa / 100.000 kelahiran hidup.[1]

Jawa tengah adalah wilayah di Indonesia yang angka kematian ibunya relatif tinggi, akhir tahun 2016 angka kematian ibu di Jawa Tengah mencapai 116/100.000 kelahiran hidup, menempati posisi ke 2 di Indonesia. Beberapa kabupaten dan kota di Jawa Tengah menjadi penyumbang tingginya angka kematian ibu diwilayah tersebut, salah satu nya adalah Kabupaten Pekalongan. Angka kematian ibu di Kabupaten Pekalongan tercatat pada tahun 2015 sejumlah 22/100.000 kelahiran hidup, jumlah tersebut mengalami penurunan di tahun 2016 menjadi 17/100.000 ditahun 2016, namun berdasarkan laporan Dinas Kesehatan Kabupaten (DKK) Pekalongan pada juni 2017 sudah tercatat 9 kasus kematian ibu di wilayah tersebut sehingga menjadi perhatian yang serius dari pemerintah daerah setempat.[2]

Tingginya angka kematian ibu dipengaruhi oleh berbagai faktor yang berhubungan dengan proses kejadian kematian ibu (determinan dekat) yang meliputi komplikasi pada kehamilan, persalinan dan masa nifas. Determinan dekat dipengaruhi oleh determinan antara yaitu status kesehatan, status reproduksi, akses pelayanan kesehatan, perilaku perawatan kesehatan (ketersediaan layanan kesehatan) dan faktor lain yang tidak terduga, faktor lainnya adalah adanya determinan jauh yang mempengaruhi determinan antara pada kasus kematian ibu, faktor ini meliputi sosio-kultural dan faktor ekonomi, seperti kedudukan wanita dalam keluarga dan masyarakat serta posisi keluarga dalam masyarakat dan status masyarakat.[3] 
Akses pelayanan kesehatan menjadi penting bagi ibu hamil dalam memeriksakan kehamilannya, terutama bagi ibu yang tinggal pada kondisi geografis dengan faktor penyulit. Data WHO menyebutkan resiko ibu mengalami kematian lebih tinggi 23 kali pada negara berkembang dibandingkan negara maju, pada daerah perkotaan dibanding daerah pedesaan baik antar negara maupun pada wilayah negara. Kesulitan akses layanan dipedesaan disebabkan oleh minimnya infrastruktur, moda transportasi, dan jauhnya tempat tinggal dengan keberadaan tempat layanan kesehatan, dan pengaturan sumberdaya yang rendah sehingga memungkinkan pelayanan kehamilan dan penolong persalinan oleh tenaga nonmedis, pengetahuan dan sikap serta kurangnya dukungan menjadikan permasalahan menjadi kian komplek.[4]

Wilayah Kabupaten Pekalongan terletak diantara 60 - 7o 23' Lintang Selatan dan antara 1090 - 109o 78' Bujur Timur, secara topografis Kabupaten Pekalongan terdiri atas wilayah datar (bagian utara) dan wilayah pegunungan dengan ketinggian 1.294 meter diatas permukaan laut (bagian selatan). Wilayah pegunungannya meliputi 20\% dari total wilayah meliputi daerah Kecamatan Petungkriyono, Kecamatan Lebak Barang, Kecamatan Paninggaran, Kecamatan Kandangserang, Talun, Doro dan sebagian wilayah Kecamatan Karangannyar dan Kajen dan $80 \%$ nya merupakan wilayah dataran rendah.[5] Dua tipe topografi yang ada di Kabupaten Pekalongan memiliki potensi karakteristik yang berbeda, kasus kematian yang berbeda dan perbedaan faktor yang mempengaruhinya.[5]

\section{METODE PENELITIAN}

Jenis penelitian yang digunakan adalah explanatory research yaitu penelitian yang menelaah objek penelitian tanpa memberi perlakuan apapun. Rancangan yang digunakan adalah deskriptif analitik dengan pendekatan cross-sectional untuk menggambarkan sebaran ibu hamil. Populasi dalam penelitian ini adalah seluruh ibu hamil yang ada di 27 wilayah Puskesmas Kabupaten Pekalongan yang berjumlah 8140 orang. 
Rumus Slovin digunakan untuk menentukan jumlah sampel sebesar 382 orang. Instrumen dalam penelitian ini menggunakan kuesioner yang memuat informasi karakteristik responden, dan praktik pelayanan antenatal care pada tenaga kesehatan serta implementasi P4K. Analisa data dengan menghitung rerata, nilai maksimum dan minimum dan distribusi frekuensi.

\section{HASIL DAN PEMBAHASAN}

\section{Hasil}

Berdasarkan wilayah Kabupaten Pekalongan terdiri atas wilayah dataran rendah dan dataran tinggi (Pegunungan), wilayah tersebut membentang dari utara ke selatan, wilayah utara didominasi oleh dataran rendah yang meliputi: Wonokerto, Wiradesa, Buaran, Bojong, Sragi, Siwalan, Kesesi, Kajen, Karanganyar, Karangdadap, Kedungwuni, Tirto, Wonopringgo, Doro. Wilayah selatan terdiri atas dataran tinggi yang membentang di selatan meliputi: Kandang Serang, Paninggaran, Talun, Lebak Barang, dan Petung Kriyono. Pembagian wilayah berdasarkan ketinggian di Kabupaten Pekalongan tahun 2011 ada dibawah ini

Tabel 1

Pembagian Wilayah Berdasarkan Ketinggian Kabupaten Pekalogan Tahun 2011 [6]

\begin{tabular}{cccclll}
\hline No & $\begin{array}{c}\text { Wilayah } \\
\text { Ketinggian } \\
\text { (meter) (dpl) }\end{array}$ & $\begin{array}{c}\text { Luas } \\
\mathbf{( H a )}\end{array}$ & $\begin{array}{c}\text { Luas } \\
(\%)\end{array}$ & \multicolumn{2}{l}{ Kecamatan } & \\
\hline 1 & $0-250$ & 381,60 & 48,08 & $\begin{array}{l}\text { Bojong, Buaran, Kajen, Karanganyar, } \\
\text { Karangdadap, Kedungwuni, Kesesi, } \\
\text { Siwalan, Sragi, Tirto, } \begin{array}{l}\text { Kiradesa, } \\
\text { Wonokerto, Wonopringgo }\end{array}\end{array}$ \\
\hline 2 & $250-500$ & 187,54 & 23,62 & Doro, Talun, Kandangserang & \\
\hline 3 & $500-750$ & 58,20 & 07,33 & Lebakbarang \\
\hline 4 & $750-1000$ & 92,98 & 11,71 & Paninggaran & \\
\hline 5 & $1000-1500$ & 73,56 & 09,26 & Petungkriyono & \\
\hline & Jumlah & 793,88 & 100,00 & & \\
\hline
\end{tabular}

Sumber: Peta dan Profil Kabupaten Pekalongan

Sebagian besar wilayah Kecamatan di Kabupaten Pekalongan ada pada dataran rendah yaitu kisaran $0 \mathrm{mdpl}$ hingga $250 \mathrm{mdpl}$, akan tetapi jika dilihat dari luas wilayahnya makan lebih dari $50 \%$ wilayah di Kabupaten Pekalongan adalah wilayah pegunungan yang membentang 
dari timur kebarat yang meliputi wilayah Petungkriyono hingga Kandangserang.

Jumlah ibu hamil di kabupaten pekalongan bervariasi, beberapa kecamatan yang ada di Kabupaten Pekalongan memiliki jumlah ibu hamil yang cukup tinggi dibandingkan dengan kecamatan yang lain, berdasarkan ketinggian wilayah masing-masing kecamatan memiliki jumlah ibu hamil yang bervariasi sebagai berikut:

Tabel 2

Jumlah Ibu Hamil Berdasarkan Wilayah Ketinggian

Kabupaten Pekalongan Tahun 2017

\begin{tabular}{|c|c|c|c|c|c|c|c|c|}
\hline \multirow[t]{2}{*}{ No } & \multirow{2}{*}{$\begin{array}{c}\text { Wilayah } \\
\text { Ketinggian } \\
\text { (meter) (dpl) }\end{array}$} & \multirow[t]{2}{*}{$\begin{array}{c}\text { Jumlah } \\
\text { Bumil }\end{array}$} & \multirow{2}{*}{$\%$} & \multirow{2}{*}{$\begin{array}{c}\text { Jumlah } \\
\text { Kematian } \\
\text { lbu }\end{array}$} & \multirow{2}{*}{$\%$} & \multicolumn{3}{|c|}{ Sebab Kematian } \\
\hline & & & & & & Eklamsia & Infeksi & Lainnya \\
\hline 1 & $0-250$ & 6984 & 85,79 & 8 & 88,88 & 6 & 1 & 1 \\
\hline 2 & $250-500$ & 973 & 11,95 & 0 & 0 & 0 & 0 & 0 \\
\hline 3 & $500-750$ & 67 & 0,82 & 0 & 0 & 0 & 0 & 0 \\
\hline 4 & $750-1000$ & 30 & 0,36 & 1 & 11,12 & 1 & 0 & 0 \\
\hline \multirow[t]{2}{*}{5} & $1000-1500$ & 86 & 1,05 & 0 & 0 & 0 & 0 & 0 \\
\hline & Jumlah & 8140 & 100 & 9 & 100 & 7 & 1 & 1 \\
\hline
\end{tabular}

Jumlah ibu hamil berdasarkan pantauan PWS KIA Dinas Kesehatan Kabupaten Pekalongan sebesar 8140 orang, jumlah tersebut terbagi sebagian besar ada diwilayah dataran rendah, sedangkan pada daerah pegunungan jumlahnya berkisar antara 14,21\%. Pada daerah dengan ketinggian diatas $1000 \mathrm{mdpl}$ hanya terdapat 1,05\% ibu hamil.

Angka kematian ibu yang ada di Kabupaten Pekalongan jumlahnya juga bervariasi, tiap kecamatan memiliki jumlah kematian yang berbeda, bahkan ada beberapa kecamatan juga tidak memiliki angka kematian ibu. Pertengahan tahun 2017 sudah terjadi kematian ibu sebanyak 9 orang. Kematian ibu adalah kejadian kematian pada ibu yang disebabkan oleh proses kehamilannya, persalinan ataupun yang terjadi karena proses nifas.[8] Jumlah kematian ibu yang ada di Kabupaten Pekalongan sebagian besar ada pada kecamatan di wilayah dataran rendah, seperti Wiradesa, Karanganyar, Kedungwuni, Tirto, Sragi, Kesesi dan kajen. Sedangkan hanya $11 \%$ yang terjadi di wilayah pegunungan seperti di Kecamatan Paninggaran dengan ketinggian wilayah 750 - 1000 mdpl. 
Kematian ibu sebagian besar disebabkan oleh adanya kasus eklamsia yang diderita oleh ibu saat menjalani kehamilannya, selain itu ibu hamil juga rawan mengalami infeksi saat menjalani kehamilan, persalinan maupun masa nifas. Dari 9 kasus kematian ibu yang terjadi di Kabupaten Pekalongan 7 kasus kamatian disebabkan oleh kejadian eklamsia, hanya 1 kasus kematian yang disebabkan oleh kasus infeksi dan 1 kasus kematian tidak diketahui sebabnya. Kasus kematian ibu yang disebabkan oleh eklamsia terjadi pada wilayah kecamatan Wiradesa, Karanganyar, Kedungwuni, Tirto, Sragi, dan Paninggaran. Sementara kasus kematian yang disebabkan oleh kasus infeksi ada di Kecamatan Sragi dan 1 kasus kematian ibu tidak diketahui sebabnya.

Jumlah kejadian kematian ibu dibandingkan dengan jumlah ibu hamil yang ada di Kabupaten Pekalongan yang dihitung tiap 100.000 kelahiran hidup digunakan untuk mengetahui angka kematian ibu. Berdasarkan data yang ada dari PWS KIA Kabupaten Pekalongan angka kematian ibu di wilayah kecamatan yang ada didataran rendah diketahui jumlahnya lebih besar yaitu 145/100.000 kelahiran hidup. Sementara diwilayah kecamatan yang ada dipegunungan angka kematian ibunya relatif lebih rendah yaitu 3/100.000 kelahiran hidup.

\section{Pembahasan}

Kondisi geografis suatu wilayah bervariasi, komponen yang paling sering ditemukan adalah kombinasi wilayah dataran rendah dan pegunungan, hal ini terjadi pada wilayah Kabupaten Pekalongan. Pada wilayah yang rendah biasanya di cirikan dengan kepadatan penduduk, sebaliknya pada wilayah pegunungan kepadatan penduduk semakin berkurang. Sebagian besar wilayah kecamatan di Kabupaten Pekalongan ada di dataran rendah yaitu antara 0 mdpl hingga 250 mdpl. Kondisi ini menyebabkan konsentrasi penduduk ada diwilayah tersebut. Sementara wilayah pegunungan dengan luas wilayah yang lebih besar dibanding wilayah dataran rendah konsentrasi jumlah penduduk juga semakin kecil, kondisi ini menyebabkan jumlah ibu hamil lebih terkonsentrasi pada 
wilayah yang ada di dataran rendah sebab kondisi sosial masyarakat tidak bisa lepas dari keadaan fisik geografisnya, sehingga keadaan fisik lingkugan akan berpengaruh terhadap konsentrasi penduduk pada suatu wilayah.[8]

Tingginya konsentrasi jumlah penduduk pada beberapa wilayah kecamatan di Kabupaten Pekalongan mempengaruhi tingginya jumlah ibu hamil yang ada diwilayah tersebut, tercatat sejumlah $85,79 \%$ ibu hamil ada diwilayah kecamatan yang masuk kategori dataran rendah. Senada dengan jumlah ibu hamil yang ada diwilayah tersebut kasus kematian juga lebih banyak terjadi pada wilayah dataran rendah. Berdasarkan data yang di keluarkan oleh PWS KIA Dinas Kesehatan Kabupaten Pekalongan sejumlah 9 kasus kematian ibu terjadi di Kabupaten Pekalongan pada pertengahan tahun 2017. Dari sejumlah kasus tersebut $88,88 \%$ terjadi pada wilayah kecamatan yang ada di dataran rendah seperti Wiradesa, Karanganyar, Kedungwuni, Tirto, Kajen, Sragi dan Kesesi, hanya 11,11\% kasus kematian terjadi di wilayah pegunungan yaitu di Kecamatan Paninggaran.

Kasus kematian ibu terjadi karena adanya faktor resiko yang menyertainya, ibu yang sedang hamil dan keluarganya harus diberkan pengetahuan yang berhubungan dengan ancaman pada saat kehamilan, persalinan dan masa nifas. Tingginya angka kematian ibu yang terjadi sebagian besar disebabkan oleh pre-eklamsia/eklamsia, hal ini dimungkinkan oleh tidak terkontrolnya faktor resiko yang ada. Kondisi geografis yang baik seharusnya menjadikan ibu dan keluarganya memiliki kemudahan untuk mengakses layanan kesehatan dan memilih petugas kesehatan yang terampil. Hanya saja ketika pegetahuan yang dimiliki ibu rendah serta keinginan untuk mengakses layanan juga rendah menjadikan ibu hamil terancam. Maka dibutuhkan peningkatan pengetahuan dan perubahan sikap pada ibu hamil guna memunculkan kewaspadaan dini dalam mencegah kematian akibat pre-eklamsia/ eklamsia.[9]

Pre-eklamsia ditandai dengan adanya hipetensi, edema, dan tingginya kadar protein urea dalam darah akibat kehamilan. Penyakit ini 
biasanya muncul pada trimester ke tiga atau sebelumnya. Pre-eklamsia menempati urutan pertama kematian ibu pada pasien yang dirujuk kerumah sakit. Kondisi ini menunjukkan masih tingginya kasus preeklamsia yang tidak terdeteksi di masyarakat dan biasanya baru berobat pada saat kondisinya sudah parah.[10] Faktor penyebab pre-eklamsia bervariasi dimulai dari determinan usia, kejadia paritas, pengetahuan ibu, pekerjaan ibu riwayat hipertensi dan juga riwayat antenatal care.[11]

Anatenatal care seharusnya menjadi hal yang penting bagi ibu hamil sebab dalam proses tersebut akan dilakukan pengawasan secara cermat dan intensif sehingga ibu hamil bisa mendapatkan perhatian sedini mungkin jika memiliki risiko kemungkinan munculnya pre-eklamsia maupun eklamsia. Perencanaan dan penyediaan layanan yang diberikan selama masa kehamilan secara berkala sesuai pedoman sangat membantu kesehatan ibu dan kandungannya. Perkembangan yang terpantau akan memunculkan saran-saran yang bisa diberikan ketika didapati keadaan yang kurang maupun yang lebih. Sehingga permasalahan bisa diatasi sebelum dan sesudah persalinan.

Kondisi geografis yang mudah seharusnya memudahkan dalam mengakses layanan antenatal care ibu hamil sehingga mampu meminimalisir faktor resiko pemicu terjadinya kematian ibu, namun tidak demikian yang terjadi di Kabupaten Pekalongan, pada wilayah kecamatan di dataran rendah angka kematian ibu jumlahnya lebih tinggi dibandingkan dengan daerah pegunungan yang memiliki banyak faktor penyulit. Disini teori model kepercayaan kesehatan (Health Belive Model Theory) berlaku. Teori ini menjelaskan bahwa perilaku kesehatan ditentukan oleh adanya keyakinan pribadi dan persepsi tentang penyakit serta strategi yang tersedia untuk mengurangi terjadinya penyakit. Pada kasus kematian ibu di wilayah dengan layanan kesehatan memadai, dan faktor penyulit geografi yang rendah dimungkinkan oleh adanya sikap masyarakat yang terlena sehingga antenatal care tidak begitu diperhatikan.

Kerentanan yang dirasakan seseorang (Perceived Susceptibility) membuat orang tersebut melakukan tindakan meminimalisir resiko dengan 
melakukan praktik antenatal care bagi dirinya agar memiliki jaminan terhadap keselamatannya. Akan tertapi berbeda dengan orang yang merasa dirinya tidak rentan karena dekatnya layanan kesehatan dan input pengetahuan yang memadai membuat orang tersebut menjadi terlena. Hambatan yang dirasakan (Perceived Barrier) yang rendah dan adanya rasa aman menjadi pemicu tidak munculnya perilaku untuk melakukan upaya pencegahan. Pemenuhan fasiltas menjadikan seseorang tidak mempersiapkan dirinya secara maksimal untuk menghadapi proses persalinan dan mempengaruhi lemahnya isyarat-isyarat untuk bertindak (Cues To Action). ${ }^{12)} \mathrm{Hal}$ ini terlihat dari penyebab kamatian ibu yang sebagian besar karena eklamsia atau pre-eklamsia yang sebenarnya bisa di ketahui dari awal kehamilan hingga saat melahirkan.

\section{SIMPULAN DAN SARAN}

\section{Kesimpulan}

Berdasarkan hasil dan pembahasan diatas dapat disimpulkan beberapa hal, antara lain:

1. Wilayah Kabupaten Pekalongan terbagi atas dataran rendah $(48,08 \%)$ dan dataran tinggi (pegunungan) sebesar $51,92 \%$.

2. Jumlah ibu hamil sebagian besar $(84,30 \%)$ terkonsentrasi di wilayah kecamatan yang ada di dataran rendah.

3. Jumlah angka kematian ibu sebagian besar $(87,50 \%)$ ada diwilayah kecamatan yang ada didataran rendah.

4. Sebagian besar sebab kematian ibu yang ada diwilayah Kabupaten pekalongan disebabkan oleh kasus penyakit eklamsia atau preeklasia.

\section{Saran}

1. Bagi Masyarakat

Hasil penelitian ini harapannya dapat menjadi tambahan informasi bagi masyarakat, khusunya mengenai kejadian kematian ibu pada 
daerah dengan geografis dataran rendah dan dataran tinggi (pegunungan).

2. Bagi Institusi

Penelitian ini harapnnya dapat menjadi masukan dan menambah khasanah ilmu baru bagi program studi kesehatan masyarakat dan khususnya bidang promosi kesehatan

3. Bagi Peneliti Selanjutnya

Penelitian ini merupakan penelitian awal (dasar) yang dapat menjadi acuan untuk penelitian-penelitian selanjutnya di bidang promosi kesehatan khususnya mengenai kaitan kondisi geografis dengan angka kematian ibu.

\section{DAFTAR PUSTAKA}

1. Indonesia. Kementrian Kesehatan RI. Sekretaris Jendral, Profil Kesehatan Indonesia Tahun 2016, Jakarta: Kementrian Kesehatan RI.2017

2. Utami, P. 2017. Berkat Program Ini Angka Kematian Ibu di Jateng Turun Signifikan, https://Jateng.merdeka.com/makro/berkat-programini-angka-kematian-ibu-di-jateng-turun-signifikan-1702017.html. Diakses 12 April 2017

3. Febrina, I. Arulita, Faktor-Faktor Resiko Yang Mempengaruhi Kematian Maternal (Studi Kasus di Kabupaten Cilacap), Magister Epidemiologi Universitas Diponegoro, Semarang, Tahun 2007.

4. Karamelaka. W, Faktor Yang Mempengaruhi Pemanfaatan Pelayanan Antenatal Care di Wilayah Kerja Puskesmas Kec. Wolo Kabupaten Kolaka Tahun 2015, FKM Universitas Halu Oleo Kendari, Tahun 2015

5. Pekalongan. Pemkab, Kondisi Umum dan Geografis Kabupaten Pekalongan, www.pekalongankab.go.id/v2/pemerintah/deskripsiwilayah/kondisi-geografis. Diakses 28 Februari 2018

6. Pekalongan. Kabupaten, Peta dan Profil Kabupaten Pekalongan, http://www.pekalongankab.go.id/v2/pemerintahan/deskripsiwilayah/peta-wilayah/528-peta-dan-profil-kabupaten-pekalongan. Diakses 05 maret 2018. 
7. Indonesia. Kementrian Kesehatan, Upaya Percepatan Penurunan Angka

Kematian Ibu.http://www.kesehatanibu.depkes.go.id./wpcontent/uploads/downl oads/2013/01/factsheet_Upaya-PP-AKI.pdf. Diakses 6 Maret 2018

8. Rochmadi.N.W, IImu Pengetahuan Sosial, Pusat Perbukuan Departemen Pendidikan Nasional. Tahun 2008

9. Wenas.R.A, Pengaruh Promosi Kesehatan Tentang Tanda Bahaya Kehamilan Terhadap Pengetahuan Ibu Hamil di Puskesmas Amurang Kabupaten Minahasa Selatan. Jurnal IImiah Bidan:Jidan

10. Indriani.N, Analisa Faktor-Faktor yang Berhubungan Dengan Preeklamsia/ Eklamsia Pada Ibu Bersalin di Rumah Sakit Umum Daerah Kardinah Kota Tegal Tahun 2011, FKM UI, Tahun 2012.

11. Wardani.K.Y.W, Analisa Faktor-Faktor Risiko yang Mempengaruhi Terjadinya Pre-Eklamsia/ Eklamsia di RSU PKU Muhammadiyah Yogyakarta Tahun 2007-2009. Stikes Aisyah Yogyakarta. Tahun 2010.

12. Karen, Frances, dkk. 1990. Health Behavior and Health Education. San Fransisco : Oxford University 


\section{PEDOMAN PENULISAN NASKAH JKM}

Jurnal Kesehatan Masyarakat (JKM) STIKES Cendekia Utama Kudus menerima naskah hasil-hasil riset, artikel ilmiah, studi/ analisa kritis, skripsi, tesis, disertasi dan tulisan ilmiah lain di bidang kesehatan masyarakat.

Naskah adalah karya asli penulis/ peneliti, bukan plagiat, saduran atau terjemahan karya penulis/ peneliti lain. Naskah khusus ditujukan kepada Jurnal Kesehatan Masyarakat (JKM) STIKES Cendekia Utama Kudus, belum pernah dipublikasikan di media lain.

Naskah yang dikirim harus disertai surat persetujuan publikasi dan surat pengantar yang ditandatangani peneliti/ penulis.

Komponen naskah:

- Judul, ditulis maksimal 150 karakter, huruf Book Antiqua, ukuran 13, spasi 1

- Identitas penulis, ditulis setelah judul. Terdiri atas nama (tanpa gelar), alamat tempat kerja, nomor telepon/hp dan alamat email.

- Abstrak dalam bahasa Indonesia dan bahasa Inggris, maksimal 200 kata, disusun dalam satu alinea, berisi masalah, tujuan, metode, hasil dan 3-5 kata kunci. Untuk naskah dalam bahasa Inggris, tidak perlu disertai abstrak dalam bahasa Indonesia.

- Pendahuluan, tanpa subjudul, berisi latar belakang, sedikit tinjauan pustaka dan tujuan penelitian.

- Metode penelitian, dijelaskan secara rinci, disain, populasi, sampel, sumber data, teknik/ instrumen pengumpul data, dan prosedur analisis data.

- Hasil dan Pembahasan, mengurai secara tepat dan argumentatif hasil penelitian, kaitan hasil dengan teori yang sesuai dan sistematis.

- Tabel atau gambar. Tabel, diberi nomor sesuai urutan penyebutan dalam teks, ditulis 1 (satu) spasi, ukuran 11. Judul singkat, padat dan jelas, terletak di atas tabel. Gambar, diberi nomor sesuai urutan penyebutan dalam teks. Judul singkat, padat dan jelas, terletak di bawah gambar.

- Simpulan dan Saran. Simpulan menjawab masalah penelitian, pernyataan tegas. Saran logis, tepat guna dan tidak mengada-ada, dan ada keterkaitan dengan keberlanjutan penelitian

- Rujukan/ referensi ditulis sesuai aturan Vancouver, urut sesuai dengan pemunculan dalam keseluruhan teks, maksimal 25 rujukan dan 75 persen merupakan publikasi dalam 10 tahun terakhir. 
Naskah sebanyak 15-25 halaman kuarto, batas atas-bawah-tepi kiri-tepi kanan (cm) : 4-3-4-3, spasi 1,5, jenis huruf: arial, ukuran 12, format Microsoft word, dalam bentuk softfle dan 3 (tiga) eksemplar dalam bentuk print out.

Naskah dikirim ke alamat : Redaksi Jurnal Kesehatan Masyarakat (JKM) STIKES Cendekia Utama Kudus, Jl. Lingkar Raya Km.05 Jepang Mejobo Kudus 59381.

Kontak langsung dapat melalui:

- Eko Prasetyo : 081228475759 / 081575435102

- Sri Wahyuningsih : 085740572288

Naskah juga dapat dikirim melalui email : jkm.cendekiautama@gmail.com

\section{Contoh penulisan daftar pustaka :}

\section{Artikel Jurnal Penulis Individu}

Sloan NL, Winikoff B, Fikree FF. An ecologic analysis of maternal mortality ratios. Stud Fam Plann 2001;32:352-355.

\section{Artikel Jurnal Penulis Organisasi}

Diabetes Prevention Program Research Group. Hypertension, insulin, and proinsulin in participants with impaired glucose tolerance. Hypertension.2002;40(5):679-86

\section{Artikel Jurnal di Internet}

Goodyear-Smith F and Arroll B, Contraception before and after termination of pregnancy: can we do it better? New Zealand Medical Journal, 2003, Vol. 116, No. 1186, <http://www.nzma.org.nz/journal/1161186/683/content. pdf>, accessed Aug. 7, 2007.

\section{Buku Dengan Nama Editor sebagai penulisnya}

Lewis G, ed. Why mothers die 2000-2002: the confdential enquiries into maternal deaths in the United Kingdom. London: RCOG Press; 2004.

\section{Buku yang Ditulis Individu}

Loudon I. Death in childbirth. An international study of maternal care and maternal mortality 1800-1950.London: Oxford University Press, 1992.50

\section{Buku yang Ditulis Organisasi}

Council of Europe, Recent Demographic Developments in Europe 2004,Strasbourg, France: Council of Europe Publishing, 2005. 


\section{Artikel dari Buletin}

Ali MM, Cleland $\mathrm{J}$ and Shah $\mathrm{IH}$, Condom use within marriage: a neglected HIV intervention, Bulletin of the World Health Organization, 2004, 82(3):180-186.

\section{Paper yang Dipresentasikan dalam Pertemuan IImiah/Konferensi}

Kaufman J, Erli Z and Zhenming X, Quality of care in China: from pilot project to national program, paper presented at the IUSSP XXV International Population Conference, Tours, France, July 18-23, 2005.

\section{BAB dalam Buku}

Singh S, Henshaw SK and Berentsen K, Abortion: a worldwide overview, in: Basu AM, ed., The Sociocultural and Political Aspects of Abortion,Westport, CT, USA: Praeger Publishers, 2003, pp. 15-47.

\section{Data dari Internet}

U.S. Bureau of the Census, International Data Base, Country summary: China, 2007, <http://www.census.gov/ipc/www/idb/country/chportal.html>, accessed Aug. 12, 2007.

\section{Disertasi}

Lamsudin R. Algoritma Stroke Gadjah Mada (Disertasi). Yogyakarta: Universitas Gadjah Mada. 1997

\section{Makalah dalam Surat Kabar}

Banzai VK, Beto JA. Treatment of Lupus Nephritis. The Jakarta Post 1989; Dec 8; Sect A.5(col 3)

\section{Kamus}

Ectasia. Dorland's Illustrated Medical Dictionary.27th ed. Philadelphia: Saunders, $1988 ; 527$ 


\title{
UCAPAN TERIMA KASIH DAN PENGHARGAAN
}

\author{
Kepada Yang Terhormat : \\ Sigit Ari Saputro, S.KM., M.Kes. \\ Universitas Airlangga, Surabaya, Indonesia \\ dr. Mahalul Azam, M.Kes. \\ Universitas Negeri Semarang, Indonesia \\ Eti Rimawati, S.KM., M.Kes. \\ Universitas Dian Nuswantoro, Semarang, Indonesia \\ Didik Sumanto, S.KM., M.Kes. (Epid) \\ Universitas Muhammadiyah Semarang, Indonesia \\ Selaku reviewer (Mitra Bestari) dari \\ Jurnal Kesehatan Masyarakat (JKM) Cendekia Utama \\ STIKES Cendekia Utama Kudus
}

